International Journal of Environment, Agriculture and Biotechnology
Vol-6, Issue-2; Mar-Apr, 2021
JJEAB
Journal Home Page Available: https://ijeab.com/
Journal DOI: $10.22161 /$ ijeab

\title{
Flood Modeling and Vulnerability Analysis of Abia State using Remote Sensing and Flood Modeler
}

\author{
C. N. Baywood ${ }^{1, *}$, R. E. Njoku², U. A. Emmanuel ${ }^{3}$, E. C. Igbokwe ${ }^{4}$ \\ ${ }^{1,2,3}$ Department of Surveying and Geo-Informatics Federal University of Technology, Owerri, Nigeria \\ ${ }^{4}$ Department of Surveying and Geoinformatics, Nnamdi Azikiwe University Awka, Nigeria \\ *Corresponding Author
}

Received: 09 Jan 2021; Received in revised form: 19 Mar 2021; Accepted: 11 Apr 2021; Available online: 28 Apr 2021 (C2021 The Author(s). Published by Infogain Publication. This is an open access article under the CC BY license (https://creativecommons.org/licenses/by/4.0/).

\begin{abstract}
This study aimed at flood modeling and vulnerability analysis of Abia State using Remote Sensing and Flood modeler. The methodology involved acquisition of Sentinel-2 imagery covering Abia State, Rainfall data and ALOS PALSAR. Image subsetting was done to extract the area of study from the acquired dataset, this was followed by analysis of DEM accuracy using root mean square error, image classification to extract the landusel landcover of the study area, surface runoff modelling to determine surface runoff potential in the study area and flood modelling. The flood frequency return as modeled by Flood Modeler indicated a $25.04 \mathrm{~km}^{2}$ inundation extent for 2-year return period, $28.10 \mathrm{~km}^{2}$ inundation extent for a 5-year period and $26.04 \mathrm{~km}^{2}$ inundation extent for a 10 -year return period. Increasing to its peak extent by $3.67 \%$ by the 5-year return period, and then decreased by $2.24 \%$ by the 10 -year return period. The surface runoff potential revealed that $35.99 \%$ of the study area with an area coverage of $1630.19 \mathrm{~km}^{2}$ had low infiltration potential, $32.51 \%$ with an area of $1472.56 \mathrm{~km}^{2}$ had moderate infiltration while $31.50 \%$ with an area of $1426.82 \mathrm{~km}^{2}$ had high infiltration. This indicated that the study area had a high extent of low surface infiltration which will lead to flooding during heavy or frequent rainfalls. This study recommends flood modeler as it is reliable for flood modeling, having been proven with correlation results of 0.8196that it fits to the ground flood points gotten during field validation.
\end{abstract}

Keywords_Flood Vulnerability, Flood Modeler, Remote Sensing, Sentinel-2, Surface Runoff.

\section{INTRODUCTION}

Floods are one of the most hazardous threats to several communities affecting mainly the economy and wellbeing of the people. Floods are usually caused by excessive runoff from precipitation or snow melt, on by coastal storm surges or other tidal phenomena (Nwilo, 2012). In 2007, the frequency distribution and causes of floods over the last thirty years has been analyzed and reported by the Dartmouth flood observatory, and a five-fold increase in the number of floods per year has been observed since the 1980s. These countermeasures rely on flood prediction capabilities, and especially, the ability to delineate potential flood inundation areas is one of the most important requirements (Hoey and Ferguson1994). Flooding in Nigeria has taken a new dimension in recent times. The latest occurred on September, 2018 where communities in about 20 states were inundated and millions of people displaced from their homes Abia state was one of the states affected by the flood event. The impact of the flood was felt by the communities, human lives were lost, properties, houses, and farmlands destroyed.

The studies of Bariweni et $a l$, (2012), Dupe et $a l$, (2013), Chidi et al, (2015), Moses and Ikechukwu, (2015) have modelled flooding in Abia State but the situation remains the same. One would argue if the problem is with the accuracy of the flood models applied or just a case of not applying the right methodology to the situation.

Flooding can be exacerbated by increased amounts of impervious surface which reduce the supply of vegetation that can absorb rainfall (Förster et al., 2020), runoff from sustained rainfall, flash floods resulting from convective 
precipitation (intense thunderstorms) or sudden release from an upstream impoundment created behind a dam (Haghizadeh et al. 2012)or floods caused by blocked drainages when water accumulates across an impermeable surface (e.g., from rainfall) and cannot rapidly dissipate.

So, in order to properly solve the problem of flooding in Abia State, a deeper understanding of the factors and mechanisms that cause and contribute to the flooding event unique to Abia State can assist towards formulating an effective methodology using flood models for flood modelling and management, thus lessening the impacts of flood in Abia State.

It is to this effect that this study aimed at flood modeling and vulnerability analysis of Abia State using Remote Sensing and Flood modeler, so that planners can have an accurate data necessary for planning and managing flooding in Abia State Nigeria.

\section{MATERIALS AND METHODS}

\subsection{Study area}

Abia is a state in the south eastern part of Nigeria located between latitude $5^{0} 00^{\prime} \mathrm{N}$ and $6^{0} 00^{\prime} \mathrm{N}$ and longitude $7^{0} 00^{\prime} \mathrm{E}$ and $8^{0} 00^{\prime} \mathrm{E}$ of the equator see figure 1.0. It occupies about 6,320 square kilometers and bounded on the north by Enugu, west by Imo State, east by Akwa Ibom and to the south by Rivers State. The southern part of the State lies within the riverine part of Nigeria, which is a lowlying rainforest. The southern portion gets heavy rainfall of about 2,400 millimeters (94 in) per year especially intense between the months of April through October. The rest of the State is moderately high plain and wooded savannaand the most important rivers are the Imo and Aba Rivers which flow into the Atlantic Ocean through Akwa Ibom State.

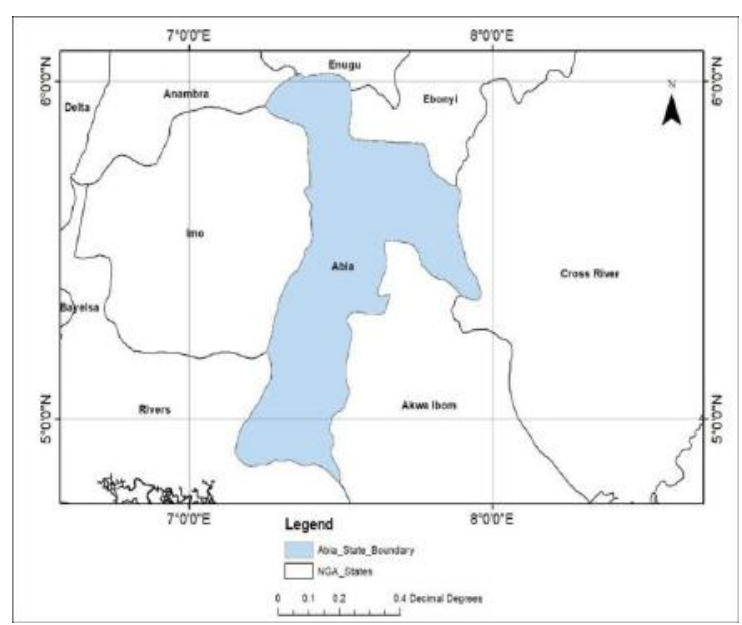

Fig.1.0: Location Map of the study area.

\subsection{Methodology}

This study utilized Sentinel-2 and ALOS PALSAR imageries of the study which were downloaded from the USGS website using the Earth explorer as the primary data. Digital administrative maps of Nigeria, Abia State which was sourced from the Department of Surveying and Geoinformatics, Nnamdi Azikiwe University Awka. Rainfall and soil data were gotten from NIMET Agency as the secondary data. Software used includes ArcGIS 10.6, Erdas Imagine 2014.

\section{RESULTS}

\subsection{Analysis of DEM Accuracy}

Before theALOS PALSAR DEM could be used in flood modelling, it had to be validated first using ground control points. The elevation points obtained from the ALOS PALSAR DEM were compared with the elevation points picked from ground to obtain the horizontal and vertical accuracy of ALOS PALSAR using root mean square error. This returned vertical and horizontal accuracies of $5.64 \mathrm{~m}$ and $14.39 \mathrm{~m}$ respectively indicating thatALOS PALSAR was a good fit and represents the elevation values on ground.

\subsection{Land Use Land Cover and Surface Runoff Modelling.}

Abia State shape file was used to subset the area of study from Sentinel 2 imagery and the resulting image was classified using supervised classification in order to obtain its LULC. The landcover/landuse distribution (figure 3.1) indicated that grassland, accounted for the largest land cover/use of about $52.06 \%$ and an area of about 2459.28 $\mathrm{km}^{2}$. Urban area had $23.21 \%$ and a coverage area of $1096.41 \mathrm{~km}^{2}$, forest had $18.36 \%$ with an area of 867.44 $\mathrm{km}^{2}$ and water body had the lowest turnout with $6.35 \%$ with an area of $300.32 \mathrm{~km}^{2}$. The precision of the classified images was ascertained and accuracy assessment was carried out by comparing the classified Landsat image with known reference pixels. The overall classification accuracy gotten was $89.23 \%$ and the overall kappa was 0.8935 .

The landcover/landuse map, rainfall data and soil map were used to model the surface runoff potential in Abia state. The landcover/landuse map, soil map and rainfall data were then used to derive the curve number map, the curve number being the one of the major governing factors that predominantly affect the runoff amount that flows over the land after satisfying all losses plays an important role in defining hydrological response of catchment. The surface runoff potential (figure 3.2) revealed that $35.99 \%$ of the study area with an area coverage of $1630.19 \mathrm{~km}^{2}$ had low infiltration potential, $32.51 \%$ with an area of 
$1472.56 \mathrm{~km}^{2}$ had moderate infiltration while $31.50 \%$ with an area of $1426.82 \mathrm{~km}^{2}$ had high infiltration. This indicated that the study area had a large extent of low surface infiltration which will lead to flooding during rainfalls.

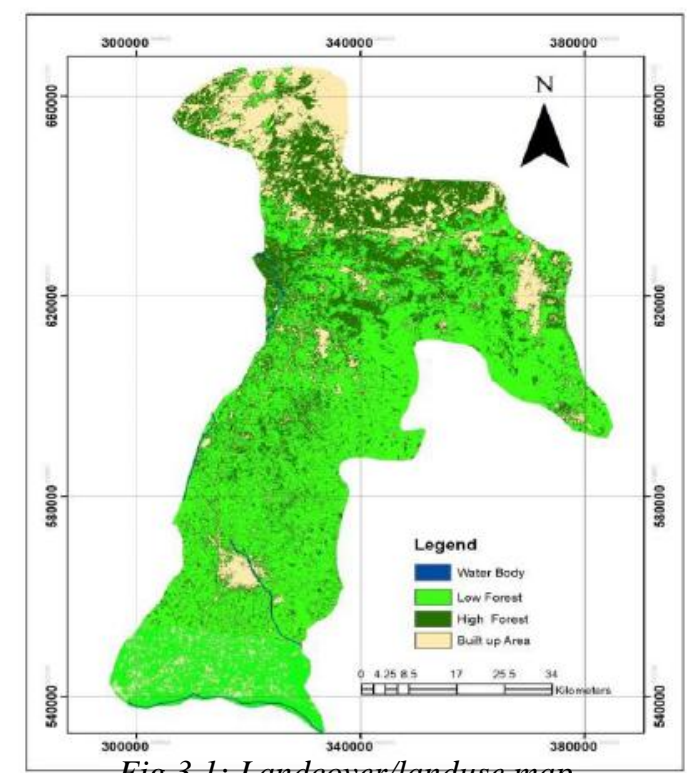

Fig.3.1: Landcoverflanduse map

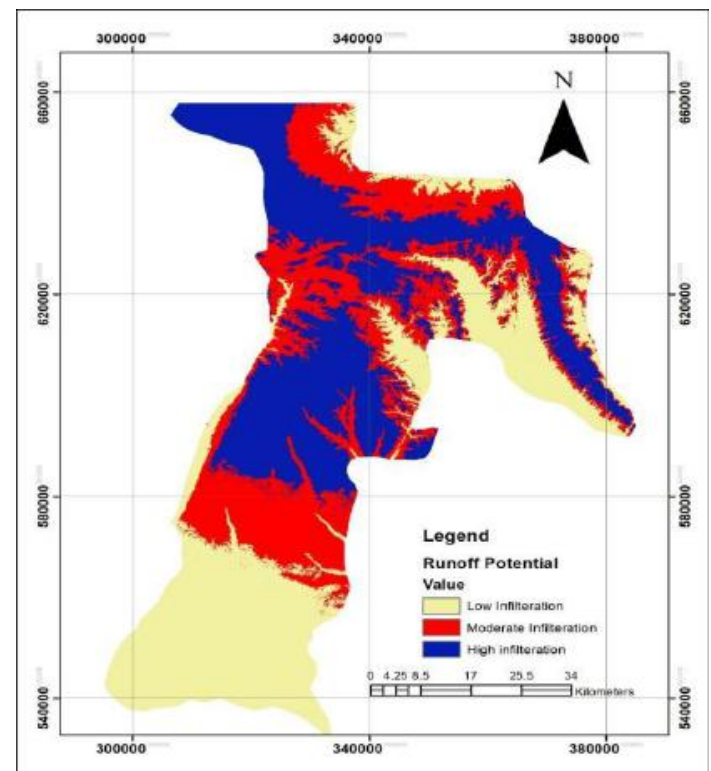

Fig.3.2: Surface runoff potential

\subsection{Flood Frequency Analysis}

The flood frequency return by flood modeler revealed a $25.04 \mathrm{~km}^{2}$ inundation extent for 2-year return period, $28.10 \mathrm{~km}^{2}$ inundation extent for a 5-year period and $26.04 \mathrm{~km}^{2}$ inundation extent for a 10 -year return period. Increasing to its peak extent by $3.67 \%$ by the 5 -year return period, then decreased by $2.24 \%$ by ten-year return period see figure 3.3 .

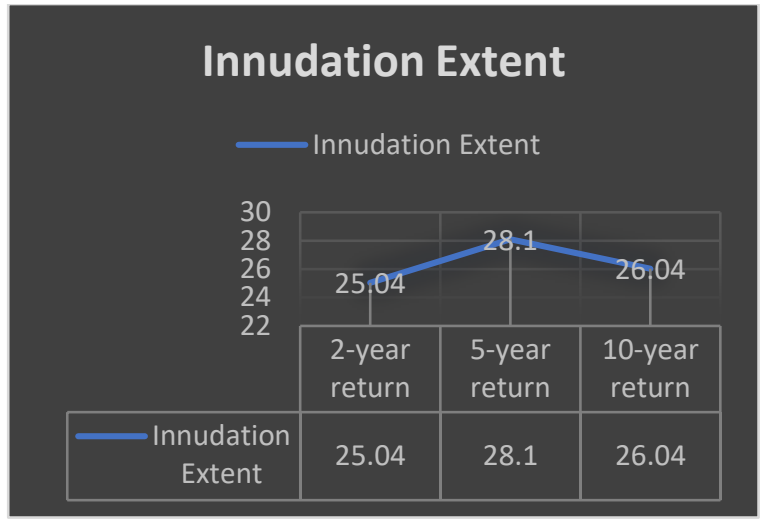

Fig.3.3: Flood frequency as modeled by Flood modeler

\subsection{Flood Vulnerability Mapping}

The results of the vulnerability modelling with flood modeler, produced a layer showing four vulnerable zones; namely very high risk, high risk, moderate risk and low risk flood zones in the study area. The results obtained from the flood modeler modelled vulnerability revealed that very high-risk zone occupied $9.69 \%$ of the entire study area, covering an area of $439.10 \mathrm{~km}^{2}$, while high risk zone occupied $27.87 \%$, covered an area of $1262.53 \mathrm{~km}^{2}$. Moderate risk zone occupied $32.87 \%$ covering $1489.25 \mathrm{~km}^{2}$ while low risk zone occupied $29.55 \%$ covering an area of $1338.71 \mathrm{~km}^{2}$ See table 3.1 .

Table 3.1 Flood vulnerability distribution by flood modeler.

\begin{tabular}{|r|l|r|r|}
\hline \multirow{2}{*}{1} & \multicolumn{3}{|c|}{ Flood Modeler } \\
\cline { 2 - 4 } & & Area (Hectare) & $\%$ \\
\hline 2 & Very High Risk & 439.10 & 9.69 \\
\hline 3 & $\begin{array}{l}\text { Moderate } \\
\text { Risk }\end{array}$ & 1262.53 & 27.87 \\
\hline 4 & Low Risk & 1489.25 & 32.87 \\
\hline & Total & 1338.71 & 29.55 \\
\hline
\end{tabular}

An overlay analysis was done, overlaying the flood risk layer with the landcover/landuse layer to determine areas at crucial very high risk. The results as modeled by flood modeler showed that built up area had $34.64 \%$ with an area of $152.12 \mathrm{~km}^{2}$, high forest had $30.94 \%$ and an area of $135.89 \mathrm{~km}^{2}$, low forest had $23.55 \%$ with an area of $103.45 \mathrm{~km}^{2}$ and waterbody had $10.96 \%$ with an area of $48.13 \mathrm{~km}^{2}$. see figures 3.4 . 


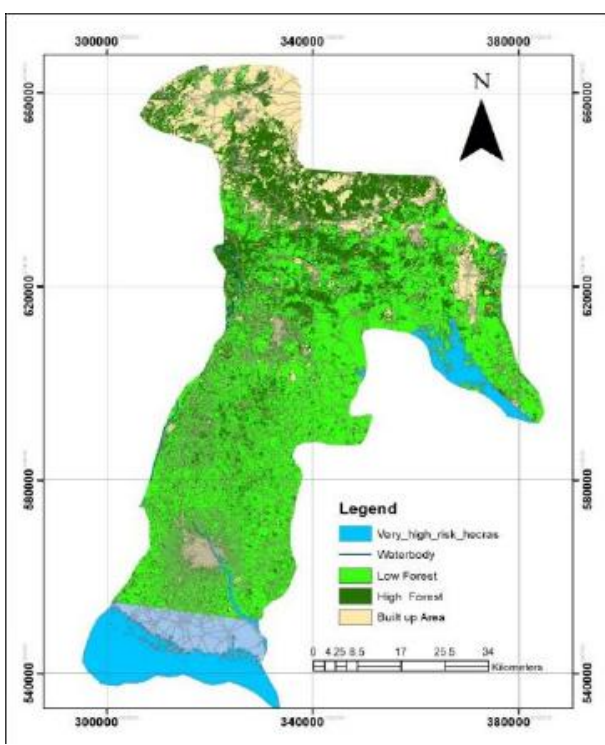

Fig.3.4: Feature at very high risk

\subsection{Ground Validation of modeling results.}

In order to determine if the results obtained fromthe modeling are reliable for flood modelling in the study area, ground validation was needed to determine the reliability and accuracy of the results. The modeled zones points were compared to flood points obtained from ground. These sample points were coded and compared using correlation coefficient.

The results of the correlation analysis revealed that the modelled result obtained a coefficient of 0.8196 and standard error of 0.48 against the ground flood points. This result indicated that flood modeler is reliable as it has a close fit to the ground flood points, see figure 3.7.



Fig.3.7: Flood modeler line fit plot against ground flood points

\section{CONCLUSION}

Flooding is considered as one of the most devastating events in many parts of the world. In terms of its frequency and distribution river flooding remains as a frequent disaster that has to be faced by civilization in flood plain. Over the years now a lot of areas in Abia State have been vulnerable to flooding. Landuse, topography, and heavy rainfalls have been the major causes of flooding in Abia State, thereby resulting in mass causalities after a flooding event.

The study was able to determine the fit and accuracy of ALOS PALAR for flood modelling in Abia State as backed by the vertical and horizontal accuracies of $5.64 \mathrm{~m}$ and $14.39 \mathrm{~m}$ respectively.

The study was able to determine the flood frequency return using Flood Modeler, which revealed a $25.04 \mathrm{~km}^{2}$ inundation extent for 2-year return period, $28.10 \mathrm{~km}^{2}$ inundation extent for a 5-year period and $26.04 \mathrm{~km}^{2}$ inundation extent for a 10 -year return period. increasing to its peak extent by $3.67 \%$ by the 5 -year return period, then decreased by $2.24 \%$ by the 10 -year return period. The study was also able to determine the surface runoff potential in Abia State. It revealed that $35.99 \%$ with an area of $1630.19 \mathrm{~km}^{2}$ had low infiltration potential, $32.51 \%$ with an area of $1472.56 \mathrm{~km}^{2}$ had moderate infiltration while $31.50 \%$ with an area of $1426.82 \mathrm{~km}^{2}$.

The approach used in this study is recommended as it is a robust and efficient tool for flood modelling in Abia State as it represents closely the flood situation on ground, also the study results is recommended to be used as tool for planning and decision making in flood control and management in the study area.

\section{REFERENCES}

[1] Bariweni, P.A.,Tawari, C.C and Abowei, J.F. (2012), Some Environmental Effects of Flooding in the Niger Delta Region of Nigeria International Journal of Fisheries and Aquatic Sciences 1(1): 35-46, 2012 ISSN: 2049-8411; eISSN: 2049-842X (C) Maxwell Scientific Organization,

[2] Chidi E. O, Felix I, and Virginia U. O. (2015), Spatial Assessment of Flood Vulnerability in Aba Urban Using Geographic Information System Technology and Rainfall Information. International Journal of Geosciences, 6, 191200

[3] Dupe N. O, Peter C N and Ayila E. (2013) From Catchment to Reach: Predictive Modelling of Floods in Nigeria.FIG

[4] Förster S., Kuhlmann B., Lindenschmidt K.-E. and Bronstert A. (2020), Assessing flood risk for a rural detention area, Nat. Hazards Earth Syst. Sci., 8, 311-322.

[5] Haghizadeh, A., Shui, L. T., Mirzaei, M., and Memarian, H. (2012). Incorporation of GIS Based Program into Hydraulic Model for Water Level Modeling on River 
Basin. Journal of Water Resource and Protection,04(01), 25-31. doi:10.4236/jwarp.2012.41004

[6] Hoey, T and Ferguson, R. (1994) Numerical simulation of downstream fining by selective transport in gravel bed rivers: Model development and illustration. Water resources research, 30, 7, 2251-2260.

[7] Moses, O. and Ikechukwu, E.O (2016) Mapping of Flood Prone Areas in Parts Of Osisioma Ngwa Local Government Area of Abia State, South-Eastern Nigeria Journal of Sustainable Development in Africa (Volume 18, No.2, 2016) ISSN: 1520-5509 Working Week 2013 Environment for Sustainability Abuja, Nigeria, 6 - 10

[8] Nwilo, P. C. (2012). Geospatial information in flooding and disaster management in Nigeria. $7^{\text {th }}$ Annual Lecture (2013) presented to Faculty of Environmental Science, Nnamdi Azikiwe university Awka, Pp (15). 